\title{
TERITORIALNI DEL REFORME LOKALNE SAMOUPRAVE V SLOVENIJI
}

\author{
Andrej Čokert \\ Služba Vlade Republike Slovenije za lokalno samoupravo in regionalno politiko, \\ Slovenska 54, SI-I000 Ljubljana \\ e-mail: andrej.cokert@gov.si \\ Pregledni znanstveni članek \\ COBISS 1.02
}

\begin{abstract}
Izvleček
Reformo lokalne samouprave v Sloveniji sestavlja pet sestavin: funkcionalno, ozemeljsko, organizacijsko, finančno-materialno in pravno. Prispevek je namenjen analizi ozemeljske sestavine. Teritorialna komponenta vključuje ustanovitev novih občin, ki so nadomestile nekdanje komune. Leta 1994 je bilo ustanovljenih 147 novih občin, namesto nekdanjih 62 komun, leta 1998 je bilo dodatno ustanovljenih 45 občin in leta 2002 še ena. Sedaj je v Sloveniji 193 občin, vendar vse ne izpolnjujejo zakonskih pogojev (5000 prebivalcev).
\end{abstract}

Ključne besede: reforma lokalne samouprave, občina, zakonodaja

\section{TERITORIAL PART OF THE REFORM OF LOCAL SELF - GOVERNMENT IN SLOVENIA}

\begin{abstract}
The reform of Slovene local self-government contains five components: functional, territorial, organisational, financial-material and legal. The article is analysing territorial component. The territorial component involves the establishment of new municipalities, which replaced the former communes. In 1994, 147 new municipalities were formed out of 62 communes, in 1998 another 45 municipalities were added and in 2002 one more. There are currently 193 municipalities in Slovenia which are not all formed according to the legislative criteria (5000 inhabitants).
\end{abstract}

Key words: reform of local self-government, municipality, legislation 


\section{UVOD}

Po osamosvojitvi Republike Slovenije je bilo uvajanje lokalne samouprave eno izmed zahtevnejših nalog v novi državi, saj je šlo pri tem za korenito spremembo dotedanje ureditve $\mathrm{v}$ smeri »klasične lokalne samouprave« evropskega tipa.

Ob uvajanju lokalne samouprave v letu 1994 reforma lokalne samouprave ni bila del koalicijskega dogovora tedanje vlade. Predlog Zakona o lokalni samoupravi je bil pripravljen v Komisiji Državnega zbora Republike Slovenije za lokalno samoupravo in ne vlada, kar je izjemen in nenavaden način priprave zakonskega predloga.

Zgodovinski pregled razvoja lokalne samouprave na Slovenskem pokaže, da je prav njena najnižja teritorialna enota - občina tista »javno pravna institucija«, ki je globoko zakoreninjena v zavesti ljudi in se je navkljub vsem velikim političnim in upravnim spremembam na območju Slovenije ohranila. Tako ima danes slovenska občina in slovenska lokalna samouprava vse značilnosti evropske lokalne samouprave.

Velike občine, ki jih je uveljavil komunalni sistem, so imele vrsto slabosti. Pretiravalo se je v avtonomnem položaju občin, večal se je upravni aparat. Zato se je pojavila težnja po večanju števila krajevnih skupnosti. Čeprav je bila krajevna skupnost uvedena že z ustavo iz leta 1963 je praktično zaživela z ustavo iz leta 1974 in se je v vseh letih delovanja izkazala kot resnična osnovna celica povezovanja in delovanja prebivalcev dela občinskega območja, kjer uresničujejo elementarne skupne interese in potrebe. Tudi ustanavljanje je bilo prepuščeno "ljudski iniciativi". Krajevne skupnosti so imele izvoljene organe vodenja in upravljanja ter predstavnike za odločanje v občinskih organih. V Sloveniji je bilo leta 1974 okoli 1050 krajevnih skupnosti, od tega $9 \%$ mestnih, ostale so bile vaške in obmestne. Število prebivalcev v njih je bilo od 60 do nekaj tisoč. Število krajevnih skupnosti se je iz leta v leto večalo, leta 1991 jih je bilo že 1173 .

Teritorialna organiziranost občin po zakonu iz leta 1964 se je spremenila šele leta 1980 ko je bilo v Sloveniji 65 občin (to je 3 več kot v letu 1964 oziroma 5 več kot v obdobju od 1966 do 1980). S tem zakonom se je mesto Maribor razdelilo na 6 občin, po spremembah 1989 pa so se 4 ponovno združile. Do uveljavitve novega sistema lokalne samouprave v samostojni Sloveniji v leta 1994, je bilo v Sloveniji 62 občin. Občine do leta 1994 so opredeljevali »da so bile do takratne občine kot komune koncipirane predvsem kot osnovna družbena in gospodarska (tudi planska) enota takratne ureditve ter enota za opravljanje dekoncentriranih nalog države (državne uprave) in zato prevelike za uresničitev vloge prave klasične občine« (Grafenauer, 2000).

\section{STROKOVNA IZHODIŠČA ZA USTANOVITEV NOVIH OBČIN}

\section{Ustavne in zakonske podlage}

Ustava Republike Slovenije v petem poglavju določa tudi teritorialno komponento občin. Občina namreč v skladu s 139. členom ustave obsega naselje ali več naselij, ki so povezana s skupnimi interesi in potrebami. Ustanovi pa se z zakonom po prej opravljenem referendumu, 
s katerim se ugotovi volja prebivalcev na določenem območju. Končno se območje občine določi z zakonom.

Zakon o lokalni samoupravi, ki je temeljni predpis, s katerim je na podlagi Ustave RS in Evropske listine lokalne samouprave, urejen sistem lokalne samouprave v Sloveniji, oziroma načela za organizacijo in delovanje samoupravnih lokalnih skupnosti, je bil sprejet konec leta 1993.

Za postopek ustanovitve občin v letu 1994 je bil sprejet poseben zakon, ki je po ustanovitvi prvih občin prenehal veljati. Zakon je urejal postopek za določitev območij, na katerih se izvede referendum za ugotovitev volje prebivalcev za ustanovitev občine ter postopek za izvedbo referenduma.

Za postopek ustanovitve občin v letu 1994 je bil sprejet poseben zakon, ki je po ustanovitvi prvih občin prenehal veljati. Zakon je urejal postopek za določitev območij, na katerih se izvede referendum za ugotovitev volje prebivalcev za ustanovitev občine ter postopek za izvedbo referenduma. Oba naslednja postopka za ustanovitev občin pa sta potekala po določbah Zakona o postopku za ustanovitev občin ter za določitev njihovih območij.

\section{Strokovna izhodišča za ustanovitev občin in referendum maja 1994}

V postopku ustanavljanja novih občin v letu 1993 oziroma 1994 sta bila v Sloveniji pripravljena dva modela teritorialne oblikovanosti občin (posebna številka Poročevalca DZ RS '94 ), ki sta temeljila na strokovno izdelanih izhodiščih. Model večjih občin je predvideval 160 občin (kriterij najmanj 5.000 prebivalcev v občini), model manjših občin je predvideval 240 občin (kriterij najmanj 3.000 prebivalcev v občini). Oba modela je na prošnjo Komisije za lokalno samoupravo tedanje Skupščine Republike Slovenije pripravil prof. dr. Igor Vrišer, ki je nato predloge strokovno predstavljal ne samo v parlamentu, ampak tudi na več deset predstavitvah po vsej Sloveniji. Na podlagi Zakona o referendumu za ustanovitev občin sta bila oba modela teritorialnega oblikovanja občin iz posebne številke Poročevalca DZ osnova za razpravo v občinah (Vlaj, 1998).

Za postopek ustanovitve občin v letu 1994 je bil sprejet Zakon o referendumu za ustanovitev občin, ki je veljal samo za vzpostavitev prve mreže občin v letu 1994. Zakon je urejal postopek za določitev območij na katerih se izvede referendum za ugotovitev volje prebivalcev za ustanovitev občine. Zakon je urejal tudi postopek za izvedbo referenduma.

Ko analiziramo zakon o referendumu za ustanovitev občin, ki je bil zakonska podlaga za spremembe $v$ teritorialni organiziranosti lokalne samouprave, ugotovimo naslednje osnovne značilnosti:

- $\quad$ referendum je bil v skladu s tretjim odstavkom 139. člena Ustave Republike Slovenije ustavna podlaga za ustanovitev občin (1. člen zakona),

- osnovna teritorialna enota za določitev referendumskega območja in občine je bilo v skladu z drugim odstavkom 139. člena Ustave Republike Slovenije, naselje ali več naselij (3. člen zakona),

- $\quad$ vse ostale določbe zakona pa so se nanašale na opravila zakonodajnega telesa države, predsednike skupščin 62 občin v Sloveniji in najširšo mogočo ljudsko iniciativo v državi, to je zbiranje podpisov v krajevnih skupnostih ali naseljih, 
- $\quad$ strokovne podlage za razpravo za določitev referendumskih območij pa pripravi in jih pošlje občinskim skupščinam Služba Vlade Republike Slovenije za lokalno samoupravo (2. odstavek 2. člena),

- državni zbor določi referendumska območja za ustanovitev občin, jih objavi v javnih občilih, po pritožbenem roku (8. člen) pa razpiše referendum s katerim se ugotovi volja za ustanovitev občin na referendumskem območju (9. člen).

Za realizacijo drugega odstavka 2. člena Zakona o referendumu za ustanovitev občin je služba Vlade Republike Slovenije za lokalno samoupravo pripravila strokovne podlage za opredelitev referendumskih območij, ki so bile objavljene v posebni številki Poročevalca Državnega zbora Republike Slovenije Gradivo je imelo uvodni sestavek z osnovnimi cilji uvedbe lokalne samouprave v Sloveniji. Temeljno gradivo so bili predlogi za opredelitev referendumskih območij, ki so bili pripravljeni na osnovi pripomb, ki so jih posredovali Državnemu zboru Republike Slovenije predstavniki občinskih skupščin in krajevnih skupnosti v obdobju po objavi »izhodišč za uvedbo lokalne samouprave«. Strokovna gradiva so bila v letu 1992 objavljena v posebni številki poročevalca takratne skupščine RS. Gradivo je bilo najobsežnejši in najtemeljitejši prikaz strokovnih prizadevanj na tem področju, ter evropsko umeščeno.

Gradivo objavljeno v posebni številki Poročevalca DZ, februar 1994, je vsebovalo predloge teritorialno manjših in teritorialno večjih občin, ter dva dodatna seznama in karti z vnesenimi 92 pripombami, ki jih je prejel Državni zbor na gradivo iz posebne številke poročevalca iz leta 1992, dodana je bila karta predlogov na gradivo iz posebne številke poročevalca iz leta 1992, dodana je bila tudi karta predlogov teritorialno večjih občin. Osnovna strokovna predloga sta predvidevala 163 občin (kriterij najmanj 5.000 prebivalcev v občini) in 249 občin (kriterij najmanj 3.000 prebivalcev v občini).

V začetku leta 1994 so imeli občani za pred obravnavo predlogov za ustanovitev novih občin torej na voljo:

- Skupščinski poročevalec RS, posebna izdaja, 30. 3. 1992,

- Zakon o lokalni samoupravi,

- Zakon o referendumu za ustanovitev občin,

- Poročevalec Državnega zbora RS, posebna številka 21. 2. 1994,

- gradivo »Zakaj v nove občine«

- gradivo Ministrstva za okolje in prostor.

Rezultat posvetovalnega referenduma za ustanovitev novih občin v maju 1994 je bilo 340 referendumskih območij za ustanovitev novih občin. Glede na nastalo situacijo (340 potencialnih občin) je v dogajanje odločilno poseglo Ustavno sodišče RS in na podlagi odločbe US (julij ' 94) je bil spremenjen 13. in 13.a člen ZLS, ki določa pogoje za ustanovitev občine in število prebivalcev - 5.000, vendar z mogočimi izjemami.Izid majskega referenduma ni omogočal, da bi povsod upoštevali izraženo voljo volivcev tako, da je vlada v septembru 1994 predlagala državnemu zboru ustanovitev 157 občin, od teh 10 mestnih občin. Predlog vlade je bil relativno konsistenten, saj je od številčnega kriterija odstopala samo tedaj, ko zaradi naravnih danosti ali večjih lokalnih nasprotovanj, območje ni dosegalo zakonskih pogojev (največje odstopanje - občina Hodoš s 450 prebivalci). Predlog vlade je v Državnem zboru RS doživel kar nekaj sprememb, tako da je bilo z Zakonom o ustanovitvi občin ter o določitvi 
njihovih območij (Uradni list RS, št.60/94, 69/94) leta 1994 ustanovljenih skupaj 147 občin, od teh 11 mestnih občin. Ustanovljeno je bilo veliko majhnih občin, nekatere pa so ostale teritorialno nespremenjene in izglasovana je bila MO Slovenj Gradec, 50 občin ni izpolnjevalo pogoja- 5.000 prebivalcev. Po lokalnih volitvah jeseni ' 94 , so občine pričele z delom januarja 1995. Kot zanimivost naj navedemo, da je državni zbor pri sprejemanju Zakona o ustanovitvi občin ter o določitvi njihovih območij zasedal dvakrat od 10. ure dopoldan do 2. oziroma 3. ure ponoči naslednjega dne.

Zaradi postopkov v državnem zboru (glasovanje za ustanovitev občin, ki ne izpolnjujejo zakonskih kriterijev, neupoštevanja stališča ministra oz. vlade) je bil v letu 1996 sprejet Zakon o postopku za ustanovitev občin ter za določitev njihovih območij (Uradni list RS, št. 44/96), ki predpisuje celoten postopek za ustanovitev občin in naj bi ob upoštevanju kriterijev iz Zakona o lokalni samoupravi, preprečil ponovitev situacije iz leta '94. Zakon je nastal kot logična posledica odločitve ustavnega sodišča, ki je od 6. do 26. oktobra 1994 prejelo eno zahtevo občinske skupščine in 79 pobud krajevnih skupnosti oziroma njihovih svetov ter posameznikov za začetek postopka za oceno ustavnosti posameznih točk 2 . in 3. člena zakona o ustanovitvi občin ter o določitvi njihovih območij in vse te zadeve združilo zaradi skupnega obravnavanja in odločanja. Ustavno sodišče RS je odločilo, da mora državni zbor najkasneje v šestih mesecih pred razpisom naslednjih rednih lokalnih volitev (leta 1998) odpraviti ugotovljene neskladnosti občin z ustavo. Za takšen rok se je ustavno sodišče odločilo tudi zaradi "upoštevanja zapletenosti in težavnosti usklajevanja območij občin in mestnih občin z ustavo". Ustavno sodišče je ocenilo, da gre pri oblikovanju občin, vključno z mestnimi občinami, za proces, v katerem se bodo te po svoji ustanovitvi še naprej oblikovale tako, da bodo čim bolj naravne in funkcionalne celote, seveda ob upoštevanju zakonskih meril. "Po konstituiranju novoustanovljenih občin bodo posamezna naselja ali več naselij v eni ali več občinah, kolikor bodo izpolnjevala pogoje za ustanovitev svoje občine ali če se bodo želela izločiti iz občine in priključiti drugi občini, lahko začela postopek po 14. ali 15. členu ZLS, ki omogočata izločitev dela občine in priključitev k drugi občini ali ustanovitev lastne občine. Takšno odločitev, ki se izglasuje na referendumu, bo po navedenem členu državni zbor potrdil, če bo odločitev skladna z ustavnim konceptom in pogoji za ustanovitev lastne občine".

Ustavno sodišče je v svoji odločbi z dne 9. 11. 1994 ugotovilo, da ustava predvideva poizvedovalni referendum, končno določitev območja občine pa je prepustila zakonodajalcu. Po mnenju ustavnega sodišča je bilo ustavno dopustno, da Državni zbor pogoja števila prebivalcev ne upošteva togo, ampak v sorazmerju z razlogi, ki opravičujejo ustanovitev občin z manj kot 5.000 prebivalci. Ustavno sodišče je sicer ugotovilo "nekaj primerov očitne arbitrarnosti, ko niso bile ustanovljene samostojne občine, čeprav so bili izpolnjeni isti pogoji kot v primerih, ko so občine bile ustanovljene". V obrazložitvi navedene odločbe je ustavno sodišče zapisalo, da "so v nasprotju z ustavo tiste točke 2. člena zakona, s katerim se ustanavljajo občine, ki ne izpolnjujejo ustavnih in zakonskih pogojev, ki jih je državni zbor sam določil kot vsebinske pogoje z ZLS”. Iz takšne obrazložitve po našem mnenju izhaja, da niso v neskladju z ustavo vse občine, ki jih določa 2. člen zakona o ustanovitvi občin ter o določitvi njihovih območij. Isto pa velja tudi za 3. člen istega zakona, ki določa 11 mestnih občin. Ustavno sodišče je ugotovilo, da druga točka 3. člena zakona (mestna občina Koper) ni v skladu $\mathrm{z}$ ustavo in da isto velja za območje mestne občine Novo mesto. Ustavno sodišče se 
"po opravljenem tehtanju prizadetih ustavnih dobrin ni odločilo, da bi ocenjevalo, ali so vse mestne občine oblikovane v skladu z ustavo".

V letu 1997 so se v okviru Službe vlade za lokalno samoupravo pričele aktivnosti v zvezi z ustanovitvijo novih občin v letu 1998 in sicer s Predlogom in predhodno opredelitvijo zaradi uskladitve 2. in 3. člena Zakona o ustanovitvi občin ter o določitvi njihovih območij z ustavo na podlagi odločb ustavnega sodišča iz novembra '94 in 95 (ustavno dopustno je, da zakonodajalec togo ne upošteva zakonskih kriterij po ZLS). Upravičeni predlagatelji po zakonu o postopku za ustanovitev občin so vložili 58 predlogov za ustanovitev občin, 8 predlogov za spremembe območij občin in 1 predlog za spremembo imena in sedeža občine ter podali 24 pobud in vlog za ustanovitev občin ter 18 pobud in vlog za spremembo območij občin.

Po opravljenih predhodnih postopkih v letih 1997 - 98, je Državni zbor RS leta '98 ustanovil 45 novih občin, tako da je sedaj v Sloveniji 192 občin, od katerih jih 95 ni izpolnjevalo kriterija 5.000 prebivalcev. Razlogov za veliko število novoustanovljenih občin leta ' 98 je več:

- odločba US RS iz 1.94 s katero je bilo ugotovljeno, da zakon o ustanovitvi občin ni v skladu $\mathrm{z}$ ustavo,

- $\quad$ ker gre pri ustanovitvi občin za politično odločanje, je tudi vlada predlagala ustanovitev občin, ki so močno odstopale od zakonskih pogojev,

- $\quad$ ustanovitev občin v Državnem zboru RS, ki niso izpolnjevale zakonskih pogojev,

- $\quad$ odločba Ustavnega sodišča RS iz aprila '98, ki je relativizirala pogoje za ustanovitev občin tako, da smo sedaj v situaciji, ko imamo natančne pogoje za ustanovitev občin (vendar 50\% občin ne izpolnjuje pogojev) in odločbo ustavnega sodišča, ki te pogoje navaja kot »programske norme«, če jih občina ne izpolnjuje.

Posebno obravnavo bi morali nameniti tudi odločitvam ustavnega sodišča, vlade in državnega zbora v zvezi z območjem Mestne občine Koper. Strokovno stališče je bilo, da je na območju občine Koper mogočih več občin, še posebej potem, ko je bil sprejet koncept mestne občine. Ustavno sodišče je v postopkih večkrat ugotovilo, in v septembru 1998 znova, da je mestna občina Koper v neskladju z ustavo in da mora državni zbor najkasneje v enem letu po uveljavitvi te odločbe na območju mestne občine Koper ustanoviti občine v skladu z ustavo. Obenem je ustavno sodišče organom mestne občine Koper podaljšalo mandat do nastopa mandata organov novih občin, ki bodo ustanovljene na tem območju. Pobudniki so ponovno opozorili, da je mestna občina teritorialno preobsežna in se sklicevali na prejšnje zadevne odločbe ustavnega sodišča, v katerih je to ugotovilo, da "mestna občina Koper po teritorialnem obsegu, številu vključenih naselij in prebivalcev in po posledični notranji heterogenosti tako močno in očitno odstopa od ustavno določenega koncepta občin, da ne ustreza območju, na katerem bi bilo mogoče ustanoviti eno občino". V obrazložitvi zadnje odločbe ustavno sodišče tudi ponovi, da "v mestno občino praviloma ne morejo biti vključena ruralna naselja.... Od določitve območja, kjer bo še zagotovljena ozemeljska povezanost, na podlagi katere se oblikuje mreža medosebnih in sosedskih odnosov ter zavest o pripadnosti ( $\mathrm{v}$ tem primeru mestni) občini, lahko zakonodajalec odstopa le toliko, kolikor je to potrebno zaradi posebne narave nalog in problemov mestne občine..." Volivci so se na referendumu aprila 1998 ponovno izrekli 
proti ustanovitvi treh novih občin: Ankaran-Škofije, Dekani in Šmarje - Marezige (strokovni predlog, ki ga je povzela vlada), državni zbor pa s spremembami in dopolnitvami ZUODNO tudi ni posegel v območje mestne občine Koper oziroma jo je ohranil v nespremenjenem obsegu. Prav tako je državni zbor zavrnil predlog vlade za ustanovitev občine Dekani.

Postopek za ustanovitev občin ter spremembo njihovih območij za ustanovitev občin v letu 2002 je potekal v luči sodelovanja vlade in večine v državnem zboru in odločenosti, da je v Sloveniji potrebno ustaviti ustanavljati nove občine. Vlada je pri oblikovanju mnenj o predlogih za preoblikovanje mreže občin smiselno upoštevala stališče ustavnega sodišča, ki ga je v obrazložitvi odločb zapisalo da je število prebivalcev pomemben element lokalne skupnosti, ker mora omogočati izvajanje lokalne samouprave ter da občina s premajhnim številom prebivalcev ne more zagotoviti učinkovitega izvajanja javnih nalog lokalnega pomena. Vlada je pogoje iz 13. in 13. a člena ZLS obravnavala kot celoto, da bi bilo odločanje o ustanovitvi občin v kar najmanjši meri arbitrarno in preprečen nastanek med seboj funkcionalno neprimerljivih občin. Ustavno sodišče je ponovno poudarilo, da je pri oblikovanju mreže občin treba upoštevati celoto vseh z zakonom urejenih meril v njihovi vzajemni povezanosti. Glede števila prebivalcev je menilo, da ga je potrebno upoštevati v sorazmerju z razlogi, ki opravičujejo ustanovitev občin z manj kot 5.000 prebivalcev. Te razloge določa drugi odstavek 13.a člena ZLS. Pogoje, ki jih mora območje izpolnjevati, da se šteje, da bo občina ustanovljena na tem območju, sposobna zadovoljevati skupne potrebe in interese prebivalstva ter naloge v skladu z zakonom, ki jih določa 13. člen ZLS, pa je po mnenju ustavnega sodišča treba razumeti tudi programsko in ne zgolj v pomenu absolutnega institucionalnega pogoja. Za sodišče je pomembno, da lokalna skupnost, ki še ni z zakonom ustanovljena kot občina, pa to želi postati, izkaže obstoj z zakonom predvidenih individualnih in kolektivnih potreb, ki naj se zadovoljujejo v novi občini. Tako je bila v letu 2002 ustanovljena ena sama občina.

Preglednica 1: Število občin glede na različne modele in dejansko stanje od 1994 do 2002

Table 1: Number of Communities according to thedifferent models and actually situation from 1994 to 2002

\begin{tabular}{|lc|}
\hline leto & število občin \\
\hline do leta 1994 & 62 \\
model večjih občin 1994 & 160 \\
model manjših občin 1994 & 240 \\
referendumska območja 1994 & 340 \\
predlog vlade 1994 & 157 \\
število občin 1994 & 147 \\
število občin 1998 & 192 \\
število občin 2002 & 193 \\
\hline
\end{tabular}




\section{STALIŠČE SVETA EVROPE (Kongresa lokalni in regionalnih oblasti Evrope) DO VELIKOSTI OBČIN V SLOVENIJI}

Svet Evrope je $\mathrm{z}$ namenom varovanja in ponovne uveljavitve lokalne samouprave v evropskih državah, predvsem pa z namenom, da se s sprejemom skupnih načel in priporočil doseže večja enotnost držav pri urejanju in uveljavljanju demokratičnih načel lokalne demokracije, sprejel in svojim članicam ponudil v podpis Evropsko listino lokalne samouprave (ELLS). Listina vsebuje načela in usmeritve, pa tudi že konkretna pravila ravnanja. Ker je listina z ratifikacijo postala del slovenskega pravnega reda, je skupaj z ustavo obvezna podlaga za zakonsko urejanje lokalne samouprave. ELLS šteje za vsebino samega pojma lokalne samouprave dve temeljni načeli (3.člen). To sta načelo avtonomije in načelo demokratičnega upravljanja, v katero sodita načeli neposrednega odločanja oziroma sodelovanja državljanov pri upravljanju javnih zadev in načelo predstavniške demokracije.

Glede na načela ELLS Svet Evrope - Kongres lokalnih in regionalnih oblasti s svojimi strokovnjaki analizira pravne ureditve lokalne samouprave držav članic in po opravljenem monitoringu sprejme usmeritve in priporočila za pravno ureditev lokalne samouprave $\mathrm{v}$ nacionalnih pravnih sistemih. Priporočila in usmeritve se nanašajo na sodelovanje državljanov pri lokalnem javnem življenju, lokalne volitve, status in delovne pogoje lokalnih in regionalnih voljenih funkcionarjev ter odgovornosti lokalnih in regionalnih voljenih funkcionarjev za njihove odločitve in dejanja. Tako je expertska skupina, ki so jo sestavljali trije ugledni strokovnjaki (poročevalca: Gerhard Engel iz ZR Nemčija, Owen Masters iz Velike Britanije ter izvedenec Heinrich Hoffschulte iz Nemčije) Kongresa lokalnih in regionalnih oblasti Sveta Evrope koncem leta 2000 in začetku leta 2001 v Sloveniji opravila nadzor. Na podlagi njenega poročila je kongres na svojem osmem zasedanju v Strasbourgu 29. - 31. maj 2001 sprejel priporočilo za pravno ureditev lokalne samouprave v Sloveniji. V delu, ki se nanaša na ustanavljanje občin v Sloveniji so zapisali, da število občin še vedno narašča. Kongres pa je $\mathrm{v}$ priporočilu poudaril:

» meni (kongres), da je zaželeno strožje izvajanje slovenskega Zakona o lokalni samoupravi, ki določa minimum 5000 prebivalcev za ustanovitev nove občine, in zaradi tega meni, da je bolje nehati ustanavljati nove občine, da se prepreči še večja razdrobljenost, združena z nezadostnim financiranjem. "

Podrobneje pa poročevalci pojasnjujejo:

»V strukturi lokalnih skupnosti še vedno prevladuje veliko število majhnih občin. To je že določena tradicija, saj je bilo leta 1952 kar 380 enot. Ena od razlag bi lahko bila, da so obstajala obdobja s centralistično tendenco po nadziranju države preko manjših enot ("divide et impera"). Po osamosvojitvi in uvedbi demokratičnih struktur je bilo v Sloveniji 60 lokalnih skupnosti in država se je odločila, da uzakoni novo organiziranost lokalnih skupnosti. Poročilo Svetu Evrope iz leta 1997 omenja že 147 lokalnih oblasti. Minimalni kriterij, ki ga je prvotno določil zakon o lokalni samoupravi, je bil 5000 prebivalcev, vendar pa ima danes 95 občin od skupno 192 število prebivalcev pod tem minimumom. Za takšen razvoj je odgovoren stari parlament (državni zbor), saj je sprejel celo vrsto “izjem" kmalu po sprejetju zakona in s tem diskreditiral minimalni kriterij. To je imelo posledice za pristojnosti Ustavnega sodišča, ki 
je moralo razsojati v več kot 60 primerih novih lokalnih razdelitev. Sodišče je izjavilo, da parlament ni spoštoval lastnih kriterijev, niti tistih za že omenjene izjeme v samem zakonu, in to izjavo ustavnega sodišča so uporabili kot podlago za "enakopravno obravnavanje" $v$ primerih, kjer je parlament zavrnil izločitev in samostojnost, to se pravi ustanovitev novih lokalnih skupnosti.

Dodaten razlog za takšno lokalno razdrobljenost je bil sedanji sistem lokalnega financiranja (glej spodaj), ki majhnim odcepljenim lokalnim skupnostim omogoča, da dobijo več državnega denarja, kot bi ga kdaj koli dobile kot del večjih lokalnih oblasti. Zaradi tega sta tako vlada kot parlament - kjer je bilo več kot 40 od 90 poslancev hkrati tudi županov - izgubila nadzor nad izvajanjem svojih lastnih odločitev, ko so bile številne od teh lokalnih skupnosti ustanovljene brez spoštovanja sprejetega kriterija najmanjšega števila prebivalcev. $\mathrm{V}$ sedanjem parlamentu je še vedno 15 (aktivnih) županov.In, kot so pokazali številni intervjuji, še vedno je veliko zahtev po ustanovitvi novih občin, ki jih je treba izpolniti. Teh dejanskih zahtev je približno 25. Leta 1994 je imela država 1.989 .500 prebivalcev. Če to število razdelimo na 147 občin, kolikor jih je bilo leta 1997, je povprečje znašalo 13.530 prebivalcev (kot povprečno število prebivalcev). Od takrat je povprečno število prebivalcev na občino v Sloveniji padlo pod 10.000 prebivalcev, kolikor znaša trenutno. To se še vedno zdi relativno visoka številka v primerjavi s 1578 v Franciji (cenzus iz leta 1990) ali 3421 v Avstriji (cenzus iz leta 1991), vendar pa to neizogibno vodi do vprašanja druge ravni lokalne samouprave, do prevzemanja odgovornosti za te naloge, ki jih majhne občine ne morejo ustrezno opravljati (načelo subsidiarnosti).«

\section{SKLEP}

Za vse tri postopke za ustanovitev občin v letih 1994, 1998 in 2002 je bila značilna velika, celo prevladujoča vloga Državnega zbora RS. Državni zbor je vse predloge vlade močno spremenil. Poslanci pri svojih odločitvah niso upoštevali zakonskih določil, niti odločb ustavnega sodišča.

Vse tri postopke za ustanovitev občin je označevala močna vloga ustavnega sodišča, ki je s svojimi presojami vzpostavljalo z ustavo skladno razumevanje načela lokalne samouprave in koncepta občine ter mestne občine. V skladu z mnenji ustavnega sodišča je z 9.členom ustave priznana lokalni skupnosti pravica do lokalne samouprave (kolektivna pravica). Ustavni koncept občine in mestne občine pa je sodišče izgrajevalo na podlagi socialnih, teritorialnih in kasneje tudi funkcionalnih ter finančno materialnih elementov lokalne samouprave.

Število občin, ki se je približalo 200 niti ni tako veliko. Povprečno še vedno občina šteje 10.000 prebivalcev. Vendar obstaja velika neuravnoteženost med njimi. Izrazito je »razdrobljena« SV Slovenija, na drugem območju (npr. JV in Z del Slovenije) pa so ostale občine $\mathrm{v}$ enakem obsegu kot pred reformo. Na izrazito ruralnih območjih so mestne občine s svojimi specifičnimi urbanimi problemi, kar nujno vodi v zapostavljanje enih ali drugih perečih problemov. Opisano pa zelo otežuje izvajanje vseh petih sestavin reforme, ki jo sestavljajo funkcionalna, ozemeljska, organizacijska, finančno-materialna in pravna. 


\title{
Literatura
}

Košak, E., 1994: Analiza omrežja naselij - središč. 1994, Ministrstva za okolje in prostor: delovno gradivo, avtor Eva Košak, julij 1994.

Grafenauer, B. 2000: Lokalna samouprava na slovenskem. Univerza Maribor Pravna fakulteta, Maribor 2000.

Mnenja Vlade Republike Slovenije o predlogih za ustanovitev občin ter za določitev oziroma za spremembo njihovih območij in za spremembo sedeža občin v letih 1994, 1998, 2002.

Poročevalec Državnega zbora RS. posebna številka 21.2.1994.

Skupščinski poročevalec RS. posebna izdaja, 30. marec 1992.

Slovenia: Reports on the situation of local and/or regional democracy drafted since the creation of the congress (May 2001). http://www.coe.int/T/E/Clrae/_5._Texts/3._Reports country_by_country/\#P803_11379

Vlaj, S. 1998: Lokalne samouprava, str. 57, Ljubljana.

»Zakaj v nove občine«. 1994: Služba Vlade RS za reformo lokalne samouprave, Ljubljana.

Zakon o ratifikaciji Evropske listine lokalne samouprave (MELLS), Uradni list RS Mednarodne pogodbe, št.15, Uradni list RS, št.57/96.

\section{TERITORIAL PART OF THE REFORM OF LOCAL SELF - GOVERNMENT IN SLOVENIA}

\begin{abstract}
Summary
The changes to the Slovenian Constitution at the end of 1991 granted Slovenian citizens the right to local self-government. The right of citizens to participate in the conduct of public affairs is one of the democratic principles common to all members of the Council of Europe. This right is exercised most directly on the local level. Such a constitutional guarantee is also in compliance with the European Charter of Local Self-Government (MELLS) ratified by Slovenia in 1996.

The reform - i.e. the introduction of new municipalities - signalled the discontinuation of the communal system in which the municipality, as a "socio-political community", primarily operated in the name of the state while the exercise of local self-government mostly took place within local communities. In comparison with present-day municipalities, a municipality was much larger at the time and not comparable to municipalities elsewhere in Europe because of the type of work it conducted.

Professional preparations for the introduction of new local self-government had been underway since 1989. In 1994 and 1995 the legislation on local self-government was adopted: the Local Government Act, the Referendum for the Establishment of Municipalities and Municipal Boundaries Act (replaced in 1996 by the Procedure for the Establishment of Municipalities and Municipal Boundaries Act), the Establishment of Municipalities and Municipal Boundaries Act, the Local Elections Act and the Financing of Municipalities Act. Pursuant to the Local Government Act and the Referendum for the Establishment of Municipalities and Municipal Boundaries Act, 147 municipalities were founded in 1994
\end{abstract}


(11 were urban municipalities); 2,800 members of municipal and city councils and 147 mayors were elected directly and commenced their work on 1 January 1995. In 1996 the said Procedure for the Establishment of Municipalities and Municipal Boundaries Act was adopted, which served as the basis for the founding of municipalities in 1998. In the second mandate period an additional 45 municipalities were formed and in the third mandate period in 2002 one additional municipality was formed; subsequently there are now 193 municipalities in Slovenia. 